\title{
ETIKA KEILMUAN DAN TANGGUNG JAWAB SOSIAL ILMUWAN (SEBUAH KAJIAN AKSIOLOGIS)
}

\author{
Hadi Kusuma Ningrat \\ Fakutas Ilmu Tarbiyah dan Keguruan IAIN Mataram
}

\begin{abstract}
Abstrak
Secara aksiologis pengembangan ilmu pengetahuan dan penggunaan teknologi harus selalu mengacu pada wawasan yang kudus dan kemanusiaan. Dengan kata lain, penekanan pada aspek vertical dan horizontal sebagai landasan moral dalam berkarya dan berinovasi merupakan keniscayaan yang harus dilakukan. Dengan berlandaskan iman dan berorientasi pada kemaslahatan manusia sebagai visi dan misi perjuangan tentu peradaban dunia akan menapaki era emas, dimana nilai-nilai kemanusiaan terjaga dan sarat nilai ketuhanan. Untuk itu, dalam konteks ini agama, etika, estetika, dan aturan adat harus tetap terjaga. Jangan sampai pengembangan ilmu pengetahuan menganut konsep barat yang sekuler dan antroposentris yang bias membuat dunia semakin berantakan dan gersang nilai ketuhanan.
\end{abstract}

Kata Kunci: etika keilmuan, tanggungjawab sosial, aksiologis 


\section{PENDAHULUAN}

Dalam sejarah kehidupan manusia ilmu telah menjadi aktor utama dalam membangun peradaban manusia sampai akhirnya dapat berbentuk peradaban semegah saat ini. Ilmu telah banyak memberikan kemudahan bagi manusia dalam memenuhi kebutuhannya dalam segala aspek kehidupan. Dengan kata lain, kehadiran ilmu telah merubah wajah dunia dari periode kuno sampai periode kontemporer. Alhasil, dengan kemajuan ilmu manusia dapat memberantas penyakit, memakai alat transportasi, membangun sarana irigasi, membangun sarana pemukiman, menikmati kemudahan komunikasi jarah jauh dan lain sebagainya (Bakhtiar, 2004:162). Jadi, tidak bisa dipungkiri bahwa peradaban manusia telah berhutang banyak kepada ilmu. Ilmu telah banyak memberikan jalan keluar bagi manusia dalam mencapai tujuannya.

Kemudian timbul pertanyaan, apakah ilmu selalu merupakan berkah dan penyelamat bagi manusia? Tidak! Disangkal atau tidak, hal itu telah terbukti. Satu sisi dengan kemajuan ilmu pengetahuan manusia dapat menciptakan berbagai bentuk teknologi. Misalnya, pembuatan bom yang pada awalnya untuk memudahkan kerja manusia, namun kemudian dipergunakan untuk hal-hal yang bersifat negatif yang menimbulkan malapetaka bagi manusia itu sendiri, seperti yang terjadi di Palu, Kantor Kedutaan Australia, Bali, dan di beberapa hotel di Jakarta. Di samping itu juga, penambangan uranium yang sejatinya dihajatkan untuk pembangkit listrik tenaga nuklir, tetapi dijadikan sebagai bom nuklir, senjata pemusnah masal. Di sinilah ilmu harus diletakkan secara proporsional dan memihak pada nilai-nilai kebaikan dan kemanusiaan. Sebab, jika ilmu tidak berpihak pada nilai-nilai, maka yang terjadi adalah bencana dan malapetaka.

Terkait hal tersebut, Bahtiar menegaskan bahwa ilmu dan teknologi harus menyesuaikan diri dengan pesan-pesan moral agama. Karena itu, setiap usaha untuk menemukan atau mencari kebenaran ilmiah seharusnya didasari atas iman dan moral agama dan bukan pada filsafat pengetahuan saja. Dengan demikian, ilmu dan teknologi tidak bebas nilai. Teknologi adalah alat yang 
dengannya ilmu dapat diterapkan untuk menghasilkan barang dan jasa. Di samping itu, ilmu dan teknologi digunakan untuk memenuhi keinginan manusia, sehingga ilmu dan teknologi tidak dapat bebas nilai, sebab keinginan manusia bersifat subjektif (Bakhtiar, 1997: 259-262).

Pengembangan dan pemakaian ilmu yang tidak di kontrol oleh apapun (baca: agama, etika, dan moral) dan tidak mengindahkan kerusakan yang dibawanya ke masyarakat, justru akan mengembalikan manusia pada habitat sebenarnya yaitu dunia binatang, di mana di dalamnya tidak berlaku hukum apapun (hukum rimba). Saling membunuh, memangsa dan dominasi yang terkuat merupakan pemandangan sehari-hari yang biasa ditemukan. Akankah dunia manusia seperti itu?

Menurut Bakhtiar (2004:248) bahwa ilmu pengetahuan yang begitu dibanggakan pada suatu saat dapat meruntuhkan suatu peradaban dan menimbulkan bencana bagi manusia. Contohnya, kematian ratusan ribu rakyat Jepang ketika bom atom dijatuhkan di Hirosima dan Nagasaki. Penemuan teknologi atom di satu sisi mendatangkan dampak yang baik, di sisi lain dapat menimbulkan bencana. Karena itu, seorang ilmuwan jika tidak mempunyai komitmen moral terhadap nilai kemanusiaan, dia bisa berbuat dengan bebas tanpa batas. Dia tidak mempermasalahkan apakah teknologi yang dihasilkannya digunakan untuk hal yang konstruktif atau yang destruktif. Di sini moral sebagai ajaran dasar agama sangat diperlukan. Hukuman yang diterima oleh para ilmuwan yang menyalahgunakan penemuannya, tidak saja kutukan dari umat manusia, tetapi juga kutukan dari Tuhan. Kalau ancaman dari Tuhan ini dapat ditanamkan lebih kuat dalam hati ilmuwan, niscaya tidak seorang pun ilmuwan yang menyalahgunakan ilmu dan teknologi.

Terkait dengan di atas, Islam sebagai agama telah banyak memberikan petunjuk tentang eksistensi ilmu, arah pengembangan ke depan dengan tetap memperhatikan etika keilmuan dan tanggung sosial. Terlebih lagi Islam (yang di dalamnya al-Qur'an) merupakan ensiklopedia ilmu pengetahuan sumber dari segala sumber ilmu pengetahuan. Jadi, dalam dunia Islam al-Qur'an merupakan landasan akhlak, moral, dan etika 
dalam pengembangan keilmuan agar ilmu dan teknologi yang dihasilkan tepat guna dan maslahat bagi peradaban manusia. Dan apapun yang dilakukan untuk pengembangan ilmu pengetahuan harus berlandaskan pada prinsip ibadah untuk mendapatkan ridha-Nya.

Dari realita dalam uraian di atas, penulis tertarik mengangkat tentang etika keilmuan dan tanggung jawab sosial ilmuwan. Topik tersebut merupakan sebuah kajian aksiologis tentang nilai dan kegunaan ilmu pengetahuan bagi kehidupan manusia. Untuk lebih jelasnya akan dideskripsikan pada pembahasan berikut ini.

\section{Konsep Etika Keilmuan dan Tanggung Jawab Sosial Ilmuwan}

Perkembangan dan kemajuan ilmu pengetahuan telah menciptakan berbagai bentuk kemudahan bagi manusia dalam memenuhi kebutuhan hidupnya. Namun apakah hal itu selalu demikian? Bahwa ilmu pengetahuan dan teknologinya merupakan berkah dan penyelamat bagi manusia, terbebas dari kutukan yang membawa malapetaka dan kesengsaraan? Memang dengan jalan mempelajari teknologi seperti pembuatan bom atom, manusia bisa memanfaatkan wujudnya sebagai sumber energi bagi keselamatan manusia, tetapi di pihak lain hal ini bisa juga berakibat sebaliknya, yakni membawa manusia kepada penciptaan bom atom yang menimbulkan malapetaka (Burhanuddin, 1997:172).

Menghadapi hal yang demikian, ilmu pengetahuan yang pada esensinya mempelajari alam sebagaimana adanya, mulai dipertanyakan untuk apa sebenarnya ilmu itu harus dipergunakan? Untuk menjawab pertanyaan seperti itu, apakah para ilmuwan harus berpaling ke hakikat moral? Bahwa ilmu itu berkaitan erat dengan persoalan nilai-nilai moral.

Keterkaitan ilmu dengan nilai-nilai moral (agama) sebenarnya sudah terbantahkan ketika Copernicus mengemukakan teorinya "bumi yang berputar mengelilingi matahari" sementara ajaran agama (Kristen) menilai sebaliknya, maka timbulah interaksi antara ilmu dengan moral yang berkonotasi 
metafisik, sedangkan di pihak lain terdapat keinginan agar ilmu mendasarkan kepada pernyataan-pernyataan yang terdapat dalam ajaran-ajaran di luar bidang keilmuan, diantaranya agama. Timbullah konflik yang bersumber pada penafsiran metafisik ini, yang berkulminasi pada pengadilan inkuisisi Galileo, yang oleh pengadilan dipaksa untuk mencabut pernyataannya bahwa bumi berputar mengelilingi matahari. Pengadilan inkuisisi Galileo ini selama kurang lebih dua setengah abad mempengaruhi proses perkembangan berpikir di Eropa. Dalam kurun waktu ini, para ilmuwan berjuang untuk menegakkan ilmu berdasarkan penafsiran alam sebagaimana adanya dengan semboyan "ilmu yang bebas nilai", setelah pertarungan itulah ilmuwan mendapatkan kemenangan dengan memperoleh keotonomian ilmu. Artinya kebebasan dalam melakukan penelitiannya dalam rangka mempelajari alam sebagaimana adanya (Suriasumantri, 2001:233).

Setelah ilmu mendapatkan otonomi yang terbebas dari segenap nilai yang bersifat dogmatis, ilmu dengan leluasa dapat mengembangkan dirinya baik dalam bentuk abstrak maupun konkret seperti teknologi. Teknologi tidak diragukan lagi manfaatnya bagi manusia. Kemudian timbul pertanyaan, bagaimana dengan teknologi yang mengakibatkan proses dehumanisasi dan kerusakan lingkungan sekitar, apakah ini merupakan masalah kebudayaan ataukah masalah moral, apabila teknologi itu menimbulkan ekses yang negatif terhadap masyarakat.

Dihadapkan dengan masalah moral dalam ekses ilmu dan teknologi yang bersifat merusak, para ilmuwan terbagi ke dalam dua golongan pendapat. Golongan pertama berpendapat bahwa ilmu harus bersifat netral terhadap nilai-nilai baik itu secara ontologis maupun aksiologis. Dalam hal ini ilmuwan hanyalah menemukan pengetahuan dan terserah kepada orang lain untuk mempergunakannya, apakah akan dipergunakan untuk tujuan yang baik ataukah untuk tujuan yang buruk. Golongan ini ingin melanjutkan tradisi kenetralan ilmu secara total, seperti pada waktu era Galileo. Golongan kedua berpendapat bahwa netralitas ilmu terhadap nilai-nilai hanyalah terbatas pada metafisik

100 BIOTA: Jurnal Tadris IPA Biologi FITK IAIN Mataram 
keilmuan, sedangkan dalam penggunaannya haruslah berlandaskan nilai-nilai moral. Golongan kedua mendasarkan pendapatnya pada beberapa hal, yakni:

1. Ilmu secara faktual telah dipergunakan secara destruktif oleh manusia, yang dibuktikan dengan adanya dua perang dunia yang mempergunakan teknologi-teknologi keilmuan.

2. Ilmu telah berkembang dengan pesat dan makin esoteric hingga kaum ilmuwan lebih mengetahui tentang ekses-ekses yang mungkin terjadi penyalahgunaan.

3. Ilmu telah berkembang sedemikian rupa di mana terdapat kemungkinan bahwa ilmu dapat mengubah manusia dan kemanusiaan yang paling hakiki seperti pada kasus revolusi genetika dan teknik perubahan sosial (Suriasumantri, 2001:235).

Berdasarkan ketiga hal di atas, maka golongan kedua berpendapat bahwa ilmu secara moral harus ditujukan untuk kebaikan manusia tanpa merendahkan martabat atau mengubah hakikat kemanusiaan. Ilmu secara aksiologis harus senantiasa menjunjung tinggi nilai kemanusiaan dan effeknya terhadap kerusakan lingkungan.

Dalam Zainuddin (2003:27),dijelaskanbahwa golongan yang berpendapat bahwa ilmu harus bersifat netral terhadap nilai-nilai baik itu secara ontologis maupun aksiologis menjadi golongan yang antroposentris. Dalam hal ini manusia merasa bebas, tidak terikat pada agama, tradisi, sistem sosial dan otoritas politik. Para ilmuan tidak lagi percaya pada agama yang dianggap membelenggu kemajuan ilmu pengetahuan. Kepercayaan terhadap agama luntur karena agama dianggap tidak mendukung pertumbuhan ilmu dan cara berpikir ilmiah. Inilah benih sejarah timbulnya sekulerisasi di Barat. Agama dianggap sebagai persoalan pribadi dan bahkan mereka antipati. Tidak salah jika mereka harus bersikap demikian. Sebab agama mereka tidak memeiliki konsep yang benar tentang ilmu pengetahuan atau setidaknya pemuka agama mereka tidak memiliki konsep tentang ilmu pengetahuan tersebut. 
Dari dua pendapat golongan di atas, kelihatannya netralitas ilmu terletak pada apistemologisnya saja, artinya tanpa berpihak kepada siapapun, selain kepada kebenaran yang nyata. Sedangkan secara ontologis dan aksiologis, ilmuwan harus mampu menilai mana yang baik dan mana yang buruk, yang pada hakikatnya mengharuskan seorang ilmuwan mempunyai landasan moral atau landasan etika dan estetika yang kuat sebagai penuntun dalam berkarya dan berinovasi. Tanpa ini seorang ilmuwan akan lebih merupakan seorang momok yang paling menakutkan yang dapat membuat dunia semakin berantakan.

Etika keilmuwan merupakan etika normatif yang merumuskan prinsip-prinsip etis yang dapat dipertanggungjawabkan secara rasional dan dapat diterapkan dalam ilmu pengetahuan. Tujuan etika keilmuan dapat menerapkan prinsipprinsip moral, yaitu yang baik dan menghindarkan dari yang buruk ke dalam prilaku keilmuannya, sehingga ia dapat menjadi ilmuwan yang mempertanggungjawabkan perilaku ilmiahnya. Etika normatif menetapkan kaidah-kaidah yang mendasari pemberian penilaian terhadap perbuatan-perbuatan apa yang seharusnya dikerjakan dan apa yang seharusnya terjadi serta menetapkan apa yang bertentangan dengan yang seharusnya terjadi (Kattsoff, 1953:353).

Pokok persoalan dalam etika keilmuan selalu mengacu kepada elemen-elemen kaidah moral, yaitu hati nurani, kebebasan dan tanggung jawab, nilai dan norma yang bersifat utilitaristik(kegunaan). Hati nurani di sini adalah penghayatan tentang yang baik dan yang buruk yang dihubungkan dengan perilaku manusia.

Nilai dan norma yang harus berada pada etika keilmuan adalah nilai dan norma moral. Lalu apa yang menjadi kriteria pada nilai dan norma moral itu? Nilai moral tidak berdiri sendiri, tetapi ketika ia berada pada/atau menjadi milik seseorang, ia akan bergabung dengan nilai yang ada seperti nilai agama, hukum, budaya, dan sebagainya. Yang paling utama dalam nilai moral adalah yang terkait dengan tanggung jawab seseorang. Norma moral menentukan apakah seseorang berlaku baik ataukah buruk dari sudut etis. Bagi seorang ilmuwan, nilai dan norma moral yang

102 BIOTA: Jurnal Tadris IPA Biologi FITK IAIN Mataram 
dimilikinya akan menjadi penentu, apakah ia sudah menjadi ilmuwan yang baik atau belum.

Penerapan ilmu pengetahuan yang telah dihasilkan oleh para ilmuwan, apakah itu berupa teknologi, maupun teori-teori emansipasi masyarakat dan sebagainya itu, mestilah memperhatikan nilai-nilai kemanusiaan, nilai agama, nilai adat, dan sebagainya. Ini berarti ilmu pengetahuan tersebut sudah tidak bebas nilai. Karena ilmu sudah berada di tengah-tengah masyarakat luas dan masyarakat akan mengujinya(Suriasumantri, 2001:237).

Oleh karena itu, tanggung jawab lain yang berkaitan dengan penerapan teknologi di masyarakat, yaitu menciptakan hal positif. Namun, tidak semua teknologi atau ilmu pengetahuan selalu memiliki dampak positif ketika berada di tengah masyarakat. Kadangkala teknologi berdampak negatif, misalnya masyarakat menolak atau mengklaim suatu pandanganpandangan yang telah ada sebelumnya, seperti rekayasa genetika (cloning manusia) yang dapat dianggap bertentangan dengan kodrat manusia atau ajaran agama. Dalam persoalan ini perlu ada penjelasan lebih lanjut. Bagi seorang ilmuwan apabila ada semacam kritikan terhadap ilmu harus menjelaskan hasil penelitiannya sejernih mungkin atas dasar rasionalitas dan metodologis yang tepat.

Saifullah (2004:47) mengemukanbahwa dalam perspektif aksiologi bahwa pada dasarnya ilmu harus dapat dipertanggungjawabkan secara, moral dan etika. Dengan kata lain ilmu harus mempunyai landasan etis atau asas moral-tidak bebas nilai. Selanjutnya, pada tataran aplikasi ilmu harus dapat digunakan dan dimamfaatkan untuk kemaslahatan manusia. Dalam hal ini ilmu dapat dimamfaatkan sebagai sarana atau alat dalam meningkatkan taraf hidup dan martabat manusia serta kelestarian atau keseimbangan alam. Untuk kepentingan manusia tersebut maka pengetahuan ilmiah yang diperoleh dan disusun dipergunakan secara komunal dan universal. Komunal berarti ilmu merupakan perngetahuan yang menjadi milik bersama, setiap orang berhak memamfaatkannya menurut kebutuhannya. Dengan kata lain, ilmu dapat dipergunakan oleh semua orang 
secara global tanpa terikat oleh aturan-aturan hidup yang bersifat diskriminatif. Sedangkan universal berarti ilmu tidak mempunyai kontasi seperti ras, ideologi atau agama.

Di bidang etika, tanggung jawab seorang ilmuwan, bukan lagi memberi informasi namun harus memberi contoh. Dia harus bersifat objektif, terbuka, menerima kritik, menerima pendapat orang lain, kukuh dalam pendirian yang dianggap benar dan kalau berani mengakui kesalahan. Semua sifat ini, merupakan implikasi etis dari proses penemuan kebenaran secara ilmiah. Di tengah situasi di mana nilai mengalami kegoncangan, maka seorang ilmuwan harus tampil ke depan. Pengetahuan yang dimilikinya merupakan kekuatan yang akan memberinya keberanian. Hal yang sama harus dilakukan pada masyarakat yang sedang membangun, seorang ilmuwan harus bersikap sebagai seorang pendidik dengan memberikan contoh yang baik(Suriasumantri, 2001:224).

Kemudian bagaimana solusi bagi ilmu yang terkait dengan nilai-nilai? Ilmu pengetahuan harus terbuka pada konteksnya, dan agamalah yang menjadi konteksnya itu. Agama mengarahkan ilmu pengetahuan pada tujuan hakikinya, yakni memahami realitas alam dan memahami eksistensi Allah, agar manusia menjadi sadar akan hakikat penciptaan dirinya, dan tidak mengarahkan ilmu pengetahuan melulu pada praxis, pada kemudahan-kemudahan material duniawi. Solusi yang diberikan oleh al-Qur'an terhadap ilmu pengetahuan yang terikat dengan nilai adalah dengan cara mengembalikan ilmu pengetahuan pada jalur semestinya, sehingga ia menjadi berkah dan rahmat kepada manusia dan alam bukan sebaliknya membawa mudharat (Hasbullah, 2000:26).

Terkait dengan wacana di atas, bagaimana dengan Islam dalam hal etika keilmuan dan tanggung jawab sosial ilmuwan? Berdasarkan sejarah tradisi Islam ilmu tidaklah berkembang pada arah yang tidak terkendali, tetapi ilmu harus bergerak pada arah maknawi dan umat berkuasa untuk mengendalikannya. Kekuasaan manusia atas ilmu pengetahuan harus mendapat tempat yang utuh, eksistensi ilmu pengetahuan bukan melulu untuk mendesak kemanusiaan, tetapi kemanusiaanlah yang 
menggenggam ilmu pengetahuan untuk kepentingan dirinya dalam rangka penghambaan diri kepada sang Pencipta.

Dalam pandangan Islam, ilmu pengetahuan memiliki peran instrumen atau sarana untuk mencapai tujuan Islam itu sendiri, yaitu kebahagiaan dunia dan akhirat. Di mana dalam kehidupan dunia manusia harus senantisa mengabdikan diri kepada Allah sebagai hamba-Nya untuk memperoleh ridha dan kebahagiaan kelak. Oleh karena itu, ilmu harus mempunyai tujuan ibadah. Dalam Islam, kecenderungan kepada wawasan yang kudus merupakan suatu keharusan, yaitu bahwa Allah adalah Zat Yang Maha Wujud, Yang Maha Mengetahui dan sumber dari segala sumber ilmu pengetahuan. Karena sumber pengetahuan dalam Islam adalah kesadaran yang Kudus, maka tujuan ilmu pengetahuan dan penggunaannya dalam kehidupan sehari-hari dalam pandangan Islam adalah kesadaran Yang Kudus pula. Jadi dalam Islam, sistem moral itulah yang akan menjadi kontrol atau kendali bagi perbuatan manusia. Ilmu tanpa kendali iman akan menyesatkan dan akan mendatangkan malapetaka. Oleh sebab itu, ilmu, iman dan amal soleh harus selalu seiring dan inheren dalam diri seorang muslim (Qadir, 1984:5)

Lebih lanjut, bahwa dalam pandangan Islam tujuan ilmu sama dengan tujuan agama, yaitu untuk kesejahteraan umat manusia. Karena ilmu memiliki perhatian besar terhadap pendidikan jiwa manusia dan pertumbuhannya, serta menghendaki kepribadian yang luhur. Dan orang yang mencari ilmu sama dengan orang yang mencari hakikat kebenaran.

Seperti yang dijelaskan Al-Maududi (1967: 37-38) dalam Islamic Way of Life, bahwa sistem moral Islam itu memiliki ciri-ciri yang komprehensif yang berbeda dengan sistem moral lainnya. Ciri-ciri tersebut antara lain sebagai berikut:

1. Keridhaan Allah merupakan tujuan hidup Muslim dan merupakan sumber standar moral yang tinggi serta menjadi jalan bagi evaluasi moral kemanusiaan. Sikap mencari ridha Allah memberikan sanksi moral untuk mencintai dan takut kepada-Nya, yang pada gilirannya mendorong manusia untuk mentaati hukum moral tanpa paksaan dari luar. Dengan 
dilandasi iman kepada Allah dan hari kiamat, manusia terdorong untuk mengikuti bimbingan moral secara sungguhsungguh dan jujur, seraya berserah diri secara ikhlas kepada Allah.

2. Semua lingkup kehidupan manusia senantiasa ditegakkan di atas moral islami sehingga moral tersebut berkuasa penuh atas semua urusan kehidupan manusia, sehingga hawa nafsu dan kepentingan pribadi tidak diberi kesempatan untuk menguasai kehidupan manusia. Moral Islam mementingkan keseimbangan dalam semua aspek kehidupan, baik individul maupun sosial.

3. Islam menuntut manusia agar melaksanakan sistem kehidupan yang berdasarkan atas norma-norma kebajikan dan jauh dari kejahatan.

Dengan demikian sistem moral dalam Islam berpusat pada sikap mencari ridha Allah, mengedalikan nafsu negatif dan kemampuan berbuat kebajikan serta menjauhi perbuatan keji dan jahat. Islam sangat mementingkan kemaslahtan umat dalam segala aspek kehidupan manusia. Jadi, sangat salah apabila ada statemen bahwa Islam adalah agama yang senang kekacauan dan peperangan.

Islam adalah manifestasi dari Al-Qur'an dan ajaran Nabi (Sunnah) yang menekankan akan pencarian ilmu pengetahuan dan penggunaannya pada jalan kebajikan. Pada saat yang sama Islam berusaha memecahkan kesatuan pemikiran dalam masalahmasalah ekonomi, politik, ilmu pengetahuan dan teknologi, agama dan masyarakat. Epistimologi Islam merupakan matriks bahwa semua elemen-elemennya berada dalam satu orientasi yang didasarkan atas jiwa manusia. Dengan kata lain, bahwa Islam merupakan totalitas, sebuah agama, sistem budaya dan juga peradaban. Dan sebagai sistem holistik, Islam menyentuh setiap aspek upaya kemanusiaan. Etika Islam dan sistem nilainya melalui sistem aktifitas kemanusiaan. Dan di samping itu Islam juga memilki perspektif definisi atas ilmu pengetahuan dan teknologi baik secara filosofis, sosiologis maupun metodologis.

Dalam aplikasinya, manusia dituntut menggunakan pengetahuannya tidak hanya untuk mengenal Tuhannya saja,

106 BIOTA: Jurnal Tadris IPA Biologi FITK IAIN Mataram 
tetapi juga untuk memberikan pelayanan kepada manusia sebaik mungkin. Pengetahuan tentang Tuhan tidak berdasarkan atas kepercayaan yang buta, tetapi atas dasar pengetahuan terhadap hukum-hukum-Nya yang universal. Oleh sebab itu, alam harus dipelihara sebaik mungkin bagi kepentingan manusia. Segala ilmu yang dipraktikan harus memiliki landasan ilmiah, sebab perbuatan tanpa dilandasi ilmu hanya akan menjadikan naif dan riskan. Hal inilah yang menjadikan motif adanya keharusan menuntut ilmu, sehingga manusia (Muslim) tidak akan berbuat tanpa adanya ilmu (Zainuddin (2003: 116-117).

Sehubungan dengan hal di atas, Islam juga sangat mengecam orang yang mengatakan sesuatu, mengerti akan ajaran-ajaran Islam, tetapi tidak melaksanakannya, sebagaimana diterangkan dalam surat Ash-Shaff ayat 39 (Depag. RI, 1989:928). Karena itu sebagai janji Allah dalam al-Qur'an (lihat QS. AlMujadilah ayat 11) (Depag. RI, 1989:910-911), bahwa jaminan keunggulan dan superioritas, termasuk kemenangan dan kesuksesan akan dikaruniakan Allah kepada mereka yang beriman dan berilmu. Beriman dalam arti mempunyai arti ketuhanan dalam hidupnya dengan menjadikan perkenan Tuhan sebagai tujuan segala kegiatannya. Dan berilmu berarti mengerti ajaran secara benar dan memahami lingkungan hidup di mana ia akan berkiprah, sosial budaya dan fisik, seperti ilmu yang dikaruniakan Tuhan kepada Adam sebagai bekal mengemban kekhalifahannya di bumi (lihat QS. Al-Baqarah ayat 31) (Depag. RI, 1989:14). Iman harus menyatu dalam diri seseorang, sebab jika tidak justru akan membuat malapetaka, bahkan lebih celaka daripada orang yang berilmu (Madjid, 1992: vii).

Selanjutnya, tentang tujuan ilmu pengetahuan, ada beberapa perbedaan pendapat antara filosof dengan ulama'. Sebagian berpendapat bahwa pengetahuan sendiri merupakan tujuan pokok bagi orang yang menekuninya, dan mereka ungkapkan tentang hal ini dengan ungkapan, ilmu pengetahuan untuk ilmu pengetahuan, seni untuk seni, sastra untuk sastra dan lain sebagainya. Menurut mereka ilmu pengetahuan hanyalah sebagai objek kajian untuk mengembangkan ilmu pengetahuan sendiri. Sebagian yang lain, cenderung berpendapat bahwa tujuan 
ilmu pengetahuan merupakan upaya para peneliti atau ilmuwan menjadikan ilmu pengetahuan sebagai alat untuk menambahkan kesenangan manusia dalam kehidupan yang sangat terbatas di muka bumi ini, ilmu pengetahuan itu utuk meringankan beban hidup manusia atau untuk membuat manusia senang, karena dari ilmu pengetahuan itulah yang nantinya akan melahirkan teknologi. Teknologi jelas sangat dibutuhkan oleh manusia utuk mengatasi berbagai masalah, seperti kebutuhan pangan, sandang, energi, kesehatan, dan lain sebagainya. Sedangkan pendapat yang lainnya cenderung menjadikan ilmu pengetahuan sebagai alat untuk meningkatkan kebudayaan dan kemajuan bagi umat manusia secara keseluruhan. Golongan ini beranggapan bahwa ilmu itu bebas nilai. lmu tidak akan berkembang apabila berada di bawah aturan yang mengekangnya (Azhim, 1989: 268).

\section{Etika Keilmuan dan Tanggung Jawab Sosial Ilmuan; SekelumitAnalisis}

Kemajuan ilmu pengetahuan dan teknologi dalam abad terakhir ini memang terasa pesat. 100 tahun yang lalu belum terbayangkan manusia mampu mengelilingi dunia dalam waktu 24 jam. Abad ke 18 belum terbayangkan munculnya media elektronik seperti televisi dan komputer. Teknologi transportasi dan informasi begitu cepat berkembangnya. Perkembangan teknologi dalam berbagai bidang berkembang pesat sejak munculnya penemuan-penemuan ilmu pengetahuan dan teknologi di barat sejak abad 17.

Penemuan ilmiah yang dimulai sejak abad ke-17 telah membuka wawasan baru bagi umat manusia. Penemuanpenemuan itu telah memberikan kemudahan bagi manusia dalam beraktifitas dan memenuhi kebutuhan hidupnya, namun pada akhirnya dengan kemudahan-kemudahan tersebut telah mengubah pola hidup masyarakat dalam berbagai aspek dan terjadinya benturan nilai lama dengan nilai baru. Apalagi pada abad 21 ini perkembangan ilmu pengetahuan dan teknologi yang semakin pesat dibarengi dengan penemuan-penemuan yang semakin mutakhir.

108 BIOTA: Jurnal Tadris IPA Biologi FITK IAIN Mataram 
Dilematis memang, di satu sisi kemajuan ilmu pengetahuan dan teknologi telah banyak memberikan kemudahan. Tetapi di sisi lain, kemajuan ilmu dan teknologi telah membuat chaos yang berkepanjangan dalam sejarah kehidupan manusia. Ini disebabkan karena ilmu pengetahuan dan teknologi dianggap bebas nilai. Bukan hal yang tidak mungkin jika ilmu pengetahuan dan teknologi bebas nilai, suatu saat akan membuat peradaban dunia hancur.

Agama dan ilmu pengetahuan menghadapi persoalan yang cukup rumit ketika berhadapan dengan situasi yang demikian. Satu sisi ilmu pengetahuan di Barat berkembang dengan pesatnya, tetapi jauh dari jiwa agama, sehingga yang terjadi adalah ilmu pengetahuan yang sekuler. Sebaliknya, di Timur masyarakatnya taat beribadah, tetapi lemah moralnya, sehingga muncul bentuk sekularisasi juga dalam umat beragama. Karena itu ada dua alternatif untuk mengatasi persolan tersebut. Pertama, menyesuaikan filsafat dan ilmu pengetahuan yang sekuler dengan ajaran agama, sehingga yang berkembang di dunia bukan filsafat dan ilmu pengetahuan yang sekuler, tetapi filsafat dan ilmu pengetahuan yang agamis. Kedua, mengutamakan pendidikan moral umat beragama, sehingga tercipta umat yang berakhlak mulia.

Untuk menyikapi permasalahan tersebut, sebuah keniscayaan juga bagi para ilmuwan untuk melakukan reorientasi visi dan misi dalam berkarya dan berinovasi, sehingga ilmu pengetahuan dan teknologi yang dihasilkan selalu memberikan yang terbaik bagi peradaban dengan tetap memelihara aturan agama, etika dan estetika. Hal tersebut karena ilmu itu tidak bebas nilai, di samping ilmu pengetahuan dan teknologi berhadapan pada konteks kehidupan.

Etika atau moral dan estetika yang menjadi ajaran dasar agama harus tertanam dalam diri ilmuwan, supaya mereka mempunyai landasan moral dalam melakukan aktifitas keilmuannya, sehingga mereka mampu memberikan yang terbaik bagi umat dan lingkungan, serta mampu dipertanggungjawabkan di depan Tuhan. 
Terkait dengan pandangan di atas, dalam konteks Islam ilmu pengetahuan dan arah pengembangannya menuju kemaslahatan umat telah banyak di atur dalam al-Qur'an dan Sunnah Nabi. Bahkan orang yang mencari ilmu, mempunyai ilmu dan mengamalkannnya dengan baik akan mendapatkan العلم penghargaan istimewa dari Tuhan. Di dalam al-Quran, kata diantaranya tersebar dalam lima surah yaitu surah al-Ahqaf ayat 23, Muhammad ayat 16, an-Najm ayat 30, al-Mujadillah ayat 11 dan al-Mulk ayat 26 (Depag. RI, 1989: 826, 832, 873, 910-911, dan 958). Ayat-ayat tersebut berkaitan dengan ilmu Allah tentang segala sesuatu dan penghargaan Allah kepada orang yang menguasai ilmu pengetahuan. Hadits-hadits Rasulullah yang menyatakan penghargaan terhadap ilmu cukup banyak. Orang yang memilik ilmu dan mengajarkannya disamakan dengan Rabbani yaitu orang yang memanfaatkan ilmunya untuk mendidik orang lain sampai ia berperilaku dewasa (Bukhari: CD Hadits).

Dalam pandangan Islam ilmu pengetahuan bernilai sakral. Kesakralannya, karena berasal dari Allah Swt dan mengfungsikannya untuk kepentingan umat mendapat gelar rabbani. Terjadinya desakralasisasi ilmu pengetahuan karena memotong pengetahuan dari akarnya. Ketika ilmu tidak kembali ke akarnya maka ilmu itu akan menjadi bebas nilai. Dalam perspektif Islam, semua ilmu tolok ukur kebenarannya adalah alQur'an, al-Sunnah dan realitas. Realitas dalam hal ini adalah sekaligus yang wujud, pengetahuan dan kebahagiaan. Ilmu pengetahuan mempunyai hubungan yang mendalam dengan realitas yang pokok dan primordial yaitu Yang Maha Suci, dan menjadi sumber dari segala yang suci.

Wawasan tentang Yang Maha Suci telah menghilang dari konsepsi Barat tentang ilmu pengetahuan. Sementara dalam Islam menjadi teori sentral al-Qur'an. Sesungguhnya yang membedakan cara berpikir Barat dan cara berpikir Islam adalah keyakinan yang tidak tergoyahkan dari cara berpikir yang dilandasi keyakinan bahwa Allah Swt menjadi sumber dari semua yang maujud. Dan dalam semua yang maujud itu termasuk ilmu pengetahuan. Oleh karena itu, tujuan ilmu pengetahuan adalah kesadaran akan adanya Yang Maha Suci, maka ilmu harus disertai dengan

110 BIOTA: Jurnal Tadris IPA Biologi FITK IAIN Mataram 
perbuatan yang bernilai suci supaya manusia terhindar dari perbuatan tercela sebagai simbol kebodohan. Dikaitan dengan itu Allah menyatakan:

- Terjemahannnya: "Ia berkata "Sesungguhnya ilmu itu disisi Allah, dan saya menyampaikan kepadamu apa yang ditugaskan kepadaku, dan aku melihat kamu adalah kaum yang bodoh (al-Ahqaf : 23). (Depag. RI, 1989:826)

- Terjemahannya: "Katakan, sesungguhnya ilmu itu di sisi Allah, sesungguhnya aku adalah pernberi peringatan yang menjelaskan" (al-Mulk: 26)(Depag. RI, 1989:958).

Lebih lanjut, al-Qur'an dalam surat al-Baqarah ayat 31-34 (Depag. RI, 1989:14) secara gamblang menyatakan dalam bentuk sebuah cerita bahwa pada awal penciptaan, Allah mengajarkan kepada Adam nama-nama benda. Adam sebenarnya merupakan sebuah simbol manusia, sedangkan "nama-nama benda" berarti unsur-unsur pengetahuan baik yang duniawi maupun bukan duniawi. Ketika Allah bertanya kepada malaikat mengenai namanama benda yang diketahuinya, para Malaikat mengakui tidak mengetahuinya dan dengan tegas mereka menyatakan kami tidak mengetahui, kecuali apa yang telah diajarkan Allah kepada-Nya. Ketika Adam diperintah Allah, untuk menjelaskan nama-nama benda, Adam dapat menjelaskannya dengan sempurna. Kemudian Allah memerintahkan supaya malaikat memberi hormat kepada Adam dan mereka melakukannya, kecuali setan yang membangkang dan oleh karenanya mendapat kutukan sebagai pengingkar dan pembangkang.

Kata memberi hormat (bersujud), merupakan simbol pengakuan atas keunggulan. Menarik untuk di-stressing bahwa keunggulan Adam atas para malaikat, lebih disebabkan karena pengetahuannya tentang nama-nama yang telah diajarkan kepadanya, dan bukan karena kesalehan semata. Dalam hal kesalehan, malaikat lebih saleh dari pada Adam. Selain itu, wahyu pertama yang diterima oleh Nabi Muhammad saw yaitu surat alAlaq(Depag. RI, 1989:1079) adalah perintah untuk membaca. 
"Bacalah dengan nama Tuhan-mu" (bacalah dengan nama Allah). Perintah ini mengisyaratkan kewajiban menuntut ilmu karena Allah. Ini mengandung makna bahwa wawasan tentang Yang Maha Suci yang memberi dasar hakiki bagi ilmu pengetahuan, harus menyertai dan memberi inti proses pendidikan pada setiap tahapannya. Allah tidak hanya berada di awal ilmu pengetahuan, tetapi juga berada diakhirnya, menyertai dan memberkati keseluruhan proses pembelajaran dan pengembangan ilmu pengetahuan.

Dalam proses ini, wawasan tentang Yang Maha Suci tidak boleh dilupakan dan seluruh proses serta aktifitas pembelajaran dan pengembangan ilmu pengetahuan hendaknya dapat diarahkan untuk mengenal ke-Maha Sucian dan Kekuasaan-Nya. Seorang mukmin mengetahui tentang Allah hanya melalui apa yang diwahyukan-Nya dalam al-Quran. Kitab suci itu merupakan sumber otentik dari pengetahuan Allah. Salah satu sifat Allah yang disebutkan dalam al-Quran ada yang berarti Yang Memiliki ilmu pengetahuan. Oleh sebab itu, memiliki pegetahuan merupakan sifat Ilahi, mencari pengetahuan menjadi kewajiban setiap mukmin dalam rangka mendekatkan diri.

Apabila setiap mukmin diwajibkan untuk mewujudkan sifat-sifat dalam keberadaannya, maka menjadi suatu keharusan bagi setiap mukmin mempercayai bahwa segala sesuatu yang ada bersumber dari Allah, dan seraya berupaya mencari dan menyerap sifat-sifat Allah dalam wujud mereka, termasuk pengetahuan, sehingga wawasan tantang Yang Maha Suci sebagai sumber pengetahuan dalam kehidupannya dan menjadi darah dagingnya. Memang, tidak semua sifat-sifat Allah dapat diserap oleh manusia mengingat sifat kodratinya yang terbatas dan berhingga. Akan tetapi setiap mukmin pasti dapat memiliki sifatsifat ilahisebanyak yang diperlukan untuk pemenuhan dalam realisasi diri. Salah satu diantaranya adalah pengetahuan, karena tanpa pengetahuan pemenuhan diri tidak akan tercapai. Pengetahuanlah yang membedakan antara manusia dan malaikat serta antara manusia dan makhluk yang lain. Dengan pengetahuan seseorang dapat mencapai kebenaran, dan kebenaran (al-haq) adalah nama lain dari Yang Riil dan Hakiki. Konsep kebenaran 
mengacu kepada memfungsikan ilmu untuk mengarahkan diri supaya seseorang berkata dan berprilaku sesuai dengan kebenaran.

Teori pengetahuan menurut Islam tidak hanya menonjolkan sudut yang khusus dari mana kaum muslimin memandang ilmu, tetapi menekankan keharusan untuk mencari ilmu. Sebagaimana telah dikemukakan bahwa perintah Allah yang pertama kepada Nabi melalui wahyu yang pertama adalah perintah membaca dengan nama Allah. Dari sudut pandang ini, membaca bukan hanya menjadi pintu masuk menuju ilmu, tetapi juga cara untuk mengetahui dan menyadari keberadaan Allah sebagai sumber pengetahuan. Al-Qur'an mewajibkan kaum muslimin menaklukan kekuatan-kekuatan alam untuk kebaikan umat manusia, dan hal itu tidak mungkin terjadi tanpa memahami ilmu murni dan ilmu terapan. Oleh sebab itu, ilmu mempunyai dua tujuan yaitu tujuan ilahiyah dan tujuan duniawiyah.

Ilmu berfungsi sebagai pertanda adanya Allah, sebab orang yang mempelajari alam dan prosesnya dengan cermat dan mendalam akan menjumpai banyak peristiwa yang menunjukan adanya tangan yang tidak tampak, yang membina dan mengawasi semua kejadian alam. Tangan itu adalah Tangan Yang Maha Kuasa dan Maha Mengetahui. Tujuan duniawi ilmu adalah untuk memungkinkan seseorang hidup sukses dengan cara memahami alam baik yang pisik maupun yang psikis kemudian memanfaatkannya untuk kemaslahatan individual dan sosial. Sedangkan tujuan ukhrawi ilmu adalah supaya dengan ilmu pengetahuan seseorang dapat mengarahkan diri untuk selalu berupaya agar semua aktifitas mempunyai nilai ukhrawi.

Demikian pentingnya ilmu pengetahuan menurut alQur'an, sehingga Allah memerintahkan Nabi untuk berdoa supaya ilmunya selalu bertambah. Bagi Nabi Muhammad Saw, ilmu pengetahuan lebih utama daripada berdoa. Mengenai haditshadits Rasulullah yang menjelaskan tentang penting dan keutamaan ilmu cukup banyak dan populer, antara lain: "Carilah ilmu walaupun sampai ke negeri cina", "Carilah ilmu sejak buaian sampai ke liang lahad" dan "Siapa saja yang menginginkan 
kebaikan di dunia hendaknya mencari ilmu dan siapa saja yang menginginkan kebahagiaan akhirat hendaknya dengan ilmu".

Oleh karena ilmu harus dicari, bahkan kalau perlu harus musafir ketempat yang jauh seperti jauh dan sulitnya menuju negeri Cina dan Madinah di zaman onta, bahkan lebih jauh daripadanya, maka Islam tidak membatasi ilmu sebatas ilmu hukum Islam saja, tetapi semua ilmu yang membawa kepada kemaslahatan duniawi dan ukhrawi baik individual maupun sosial.

Kebenaran ilmu dalam Islam harus dapat dibuktikan baik secara rasional normatif maupun rasional empiris. Tiada dogma bagaimanapun keramat dan tuanya, yang diterima dalam Islam, kecuali ilmu itu telah diuJi secara normatif dan empirik. Al-Qur'an menantang kaum penganut kepercayaan yang palsu supaya menunjukan bukti-bukti tentang kebenarannya. Mereka yang tidak menerima kebenaran al-Qur'an sebagai sumber kebenaran ditantang untuk menulis satu surat saja, Jika memang mereka masih meragukan kebenaran al-Quran yang sangat banyak memiliki data empiris dan rasional, dan jauh lebih banyak dari sekadar pengetahuan manusia yang ditemukan melalui penelitian bertahun-tahun untuk menemukan suatu penemuan, yang bahkan masih mengandung kebenaran yang relatif. Sebagaimana dalam surat al-Baqarah ayat 23, yaitu:

Terjemahannya: "Dan jika kamu dalam keraguan tentang kebenaran al-Qur'an yang kami turunkan kepada hamba Kami (Muhammad), buatlah satu surat saja yang sama dengan al-Quran dan ajaklah penolong-penolongmu selain Allah, jika kamu orang-orang yang benar" (al-Baqarah: 23) (Depag. RI, 1989:12).

Al-Quran juga menekankan begitu pentingnya bukti dan kesahihan data, sehingga menasihatkan orang-orang yang beriman supaya tidak menerima informasi yang belum jelas sumber dan kebenarannya dan tidak menyikapi sesuatu pendapat atau pernyataan tanpa dasar pengetahuan yang dapat dipertanggung-jawabkan baik di sisi Allah maupun ke khalayak ramai. 
Terjemahannya: "Dan Janganlah kamu menyikapi sesuatu yang kamu tidak memiliki pengetahuan tentangnya. Sesungguhnya pendengaran, penglihatan dan hati semuanya akan diminta pertanggung-jawabannya (al-Isra':36)(Depag. RI, 1989:429).

Ayat di atas mengisyaratkan larangan untuk membuat pernyataan yang berdasar pada data yang tidak valid dan tidak dapat dipertanggung-jawabkan secara empiris maupun normatif. Main tebakan dan perkiraan semata harus dihindari karena pengetahuan tanpa dasar yang jelas adalah sama dengan berbuat dosa.

Ada satu prinsip ilmu pengetahuan bahwa proposisi itu tidak lebih dari suatu pernyataan yang mungkin saja benar atau tidak benar. Proposisi itu akan benar jika didukung oleh bukti dan data yang valid dan reliable. Di sinilah arti pentingnya ilmu metode penelitian atau methodologi research dan penerapannya untuk memperoleh data yang sahih dan akurat. Haruslah menjadi suatu prinsip bahwa suatu bukti yang diambil dari tradisi harus dirubah, apabila ternyata bertentangan dengan data empiris hasil indra.

Dengan demikian, ilmu dan kebenaran tidak bisa dipisahkan. Artinya, suatu ilmu akan memiliki nilai kebenaran bila didukung oleh sumber data normatif dan empiris yang valid dan reliable. Kebenaran harus berdasar pada ilmu yang dapat dipertanggungjawabkan secara moral dan sosial dihadapan Tuhan Yang Maha Suci sebagai sumber semua ilmu pengetahuan.

\section{PENUTUP}

\section{Kesimpulan}

Dari uraian di atas dapat disimpulkan bahwa hal terpenting yang perlu diperhatikan dalam pengembangan keilmuan dan teknologi adalah dimensi aksiologis. Dimensi aksiologis adalah dimensi manfaat dan/atau kemaslahatan dari 
ilmu dan teknologi yang dihasilkan dan/atau digunakan. Ilmu dan teknologi tidak bebas nilai, harus terikat oleh aturan agama, etika, estetika, dan moral. Khusus dalam Islam, pengembangan ilmu pengetahuan dengan berlandaskan pada wawasan yang kudus merupakan suatu keharusan, yaitu Allah adalah Zat Yang Maha Wujud, Yang Maha mengetahaui dan sumber dari segala ilmu pengetahuan. Segala bentuk aktivitas yang dilakukan harus diniatkan sebagai ibadah untuk mendapatkan ridha-Nya. Dengan demikian, ilmu dan teknologi yang dikembangkan dan/atau digunakan oleh ilmuan dapat dipertanggungjawabkan baik secara vertikal maupun horizontal. Pada akhirnya, peradaban manusia pun akan berdinamika dalam koridor yang jelas dan benar. Dunia berdamai dalam harmoni.

\section{DAFTAR PUSTAKA}

Al-Bukhari, Shahih Bukhari Kitab al-'Ilm, CD. Hadis.

Al-Maududi, AbulA'la, Islamic Way of Life, Islamic Publication, Lahore, 1967.

Azhim, Ali Abdul, Epistemologi dan Aksiologi Ilmu Pengetahuan Perspektif Al-Qur'an, PT. RemajaRosdakarya, Bandung, 1989.

Depag RI, Al-Qur'an danTerjemahannya, CV. Toha Putra, Semarang, 1989.

Bakhtiar, Amsal, Filsafat Ilmu, PT RajaGrafindo Persada, Jakarta, 2004.

------, Filsafat Agama 1, PT Logos Wacana Ilmu, Jakarta, 1997.

Hasbullah, Moeflieh (ed), Islamisasi Ilmu Pengetahuan, PT. Pustaka Cidesindo, Jakarta, 2000.

Kattsoff, Louis 0., Elemens of Phlosophy, The Roland Press Company, New York, 1953.

Madjid, Nurcholish, Islam DoktrindanPeradaban, YayasanParamadina, Jakarta, 1992.

Qadir, C.A., Filsafat dan Ilmu Pengetahuan dalam Islam, Yayasan Obor, Jakarta, 1989.

116 BIOTA: Jurnal Tadris IPA Biologi FITK IAIN Mataram 
Saifullah, Konsep dasar Filsafat Ilmu, Program Pascasarjana UIN Malang, Malang, 2004.

Salam, Burhanuddin, Logika Materil; Filsafat Ilmu Pengetahuan, PT Rineka Cipta, Jakarta, 1997.

Suriasumantri, Jujun S., Filsafat Ilmu Sebuah Pengantar Populer, Pustaka Sinar Harapan, Jakarta, 2001.

Zainuddin, M., Filsafat Ilmu Perpektif Pemikiran Islam, Bayumedia Publishing, Malang, 2003. 